J. Dairy Sci. 91:4453-4453

doi:10.3168/jds.2008-1608

(c) American Dairy Science Association, 2008.

\title{
Letter to the Editor: New Terminology in the Journal of Dairy Science
}

\section{S. Pyörälä ${ }^{1}$}

University of Helsinki, Faculty of Veterinary Medicine, Department of Production Animal Medicine, Helsinki, Finland

In some recently published papers in the Journal of Dairy Science, new terminology was introduced. The terms were new at least to me as a nonnative speaker of English. I would like to know the definition for the term "generic mastitis" (Bar et al., 2008) and how it differs from the simple term "mastitis." I understand that the aim is to present information on mastitis caused by different pathogens. Another term used was "nonambulatory cows" and its counterpart "no nonambulatory cows" (Green et al., 2008). Eventually I understood that the term referred to recumbent cows and normal, walking cows. I would suggest that only defined, well- established terms understandable to all readers should be used in this scientific journal.

\section{REFERENCES}

Bar, D., Y. T. Gröhn, G. Bennett, R. N. González, J. A. Hertl, H. F. Schulte, L. W. Tauer, F. L. Welcome, and Y. H. Schukken. 2008. Effects of repeated episodes of generic clinical mastitis on mortality and culling in dairy cows. J. Dairy Sci. 91:2196-2204.

Green, L., J. E. Lombard, L. P. Garber, B. A. Wagner, and G. W. Hill. 2008. Factors associated with occurrence and recovery of nonambulatory dairy cows in the United States. J. Dairy Sci. 91:2275-2283.

Received August 5, 2008.

Accepted August 22, 2008.

${ }^{1}$ Corresponding author: satu.pyorala@helsinki.fi 